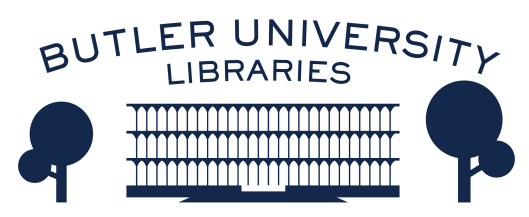

Journal of Hindu-Christian Studies

Volume 24

Article 16

November 2011

\title{
Book Review: "The South Indian Pentecostal Movement in the Twentieth Century"
}

Eliza F. Kent

Follow this and additional works at: https://digitalcommons.butler.edu/jhcs

Part of the Religion Commons

\section{Recommended Citation}

Kent, Eliza F. (2011) "Book Review: "The South Indian Pentecostal Movement in the Twentieth Century"," Journal of Hindu-Christian Studies: Vol. 24, Article 16.

Available at: https://doi.org/10.7825/2164-6279.1493

The Journal of Hindu-Christian Studies is a publication of the Society for Hindu-Christian Studies. The digital version is made available by Digital Commons @ Butler University. For questions about the Journal or the Society, please contact cbauman@butler.edu. For more information about Digital Commons @ Butler University, please contact digitalscholarship@butler.edu. 
negative stereotypes of Christianity. "Therefore," James writes, "the perception is that televangelism is, at best, another carrier of Western, secular modernity, and at worst, part of an international conspiracy to divide India" (208).

The book is, unfortunately, beset by numerous and significant problems. It ranges broadly, so much so that the focus on Indian televangelism is for long stretches nearly completely lost. Moreover, the book frequently wanders in a desultory fashion into peripheral and sometimes completely irrelevant material (e.g., India's seven main "physical types," pg. 81) that not only distracts from the primary theme of the book, but also compels the author to deal with topics beyond his area of expertise (and to do so, because of space constraints, only cursorily). He argues, for example, that Hinduism influenced the development of Charismatic Christianity in the West. The argument is plausible, perhaps, but would require the marshaling of a great deal more evidence than he supplies. He also stumbles somewhat clumsily into debates about Indian Christian history, contending with some confidence that St. Thomas did indeed establish the Indian Christian community, and arguing again without the proper marshaling of evidence that early Indian Christian writing influenced the development of Tamil literature from the first century onwards (61). And his sources on Hinduism (e.g., H. P. Griswold, from 1912; L. S. S. O'Malley, from 1935) are often outdated and somewhat prone to essentialization.

There are, in addition, a number of methodological issues. For examples, James frequently includes suggestive lists where fuller explanations or arguments are necessary, and a number of his tables are organized confusingly. At times, he also reads a bit too much into his own survey data, and there is at least one blatant statistical error (on pg. 140, when a survey response given by 53 percent of 30 Charismatic pastors and 46 percent of 30 non-Charismatic pastors is said to have been given by a "combined 99 percent"). His content analysis involves the relatively superficial counting of particular words and phrases (e.g., "anointing in the spirit") without reference, as is the current trend today, to the context of those words, and their relationship to other words and phrases in the programming analyzed. $\mathrm{He}$ also leaves completely unexplored the audience's reception and understanding of these particular words and phrases, which, given the cross-cultural and multilingual elements involved in the Indian consumption of global televangelism, would have been an intriguing topic indeed.

Finally, the book also betrays a bias, subtle at first but more explicit towards the end, in favor of "pre-colonial" (particularly Syrian) forms of Christianity, which "maintained the fabric of Hindu culture while being Christian in faith and Syrian in liturgy" (209) and against Charismatic televangelism, which is "grounded in feelings and signs rather than theological objectivity" (xxii), rejects what are implied to be the true Christian understandings of "Christian discipleship and maturity" (5), reduces the "sacred act of worship...to a series of choices in the supermarket of Christianity" (199), and unlike "liturgy in Church" which "celebrates the sacrificial life of Christ...celebrates [instead] the life of the individual and objectifies the body..." (197).

McDonaldisation, Masala McGospel and $\mathrm{Om}$ Economics is therefore an eminently mixed bag, with some value and full of potential, much of it, unfortunately, unrealized.

Chad M. Bauman Butler University

\section{The South Indian Pentecostal Movement in the Twentieth Century. Michael Bergunder. Grand Rapids, Mich.: Wm. B. Eerdmans Publishing Company, 2008. xii+380 pp.}


THE appearance in English of Michael Bergunder's study of the south Indian Pentecostal movement in the twentieth century (originally published in German in 1999) marks a valuable contribution to the emerging literature on global Pentecostalism. The book is divided into two parts - history and beliefs and practices. In addition, three appendices testify to Bergunder's emphasis on empirical methods and provide a wealth of information in the form of selected biographies of important Pentecostal leaders, a breakdown of missionaries and leadership positions by denomination, and church statistics organized by state.

Bergunder's study begins with a detailed history of the broad network of Pentecostal missions and missionaries in south India from 1906 to the 1990s. Starting with a short discussion of Pandita Ramabai's Mukti Mission (which eventually backed away from Pentecostalism, but was influential in the very beginning), Bergunder painstakingly narrates the movement of individuals, their spouses, associates, children and in-laws, from one church or region to another. While many churches were founded by foreign missionaries, a host of internal schisms and the restlessness of Indian evangelists seeking to establish their own churches soon led to the creation of a far-flung constellation of congregations and denominations across what are now Kerala, Tamil Nadu, Andhra Pradesh and Karnataka. The detail with which Bergunder describes the growth of this network is necessary for substantiating the book's main argument, which is that Pentecostalism was a global phenomenon from the beginning, contrary to Western-centric narratives that regard it as an aggressive American export. Eschewing definitions of Pentecostalism that focus on shared creeds, practices or institutions, Bergunder identifies it as "a vast and vague international network" consisting of historical connections going back in time to the beginning of Pentecostalism, and on-going communicative links between different churches, organizations and individuals who share theological styles and oral tradition and thus maintain some sort of "common Pentecostal identity" (11-13).

Bergunder demonstrates that early
Pentecostals believed that their glossalalia actually was the foreign languages missionaries needed to carry the gospel to the world (see also work by William Faupel and Gary B. McGee). The famous Asuza Street congregation in Los Angeles, long heralded as the originary font of Pentecostal spirituality, had a distinctly global outlook embodied in its eager anticipation of a world-wide revival that would augur the Second Coming of Christ. Bergunder argues that speaking in tongues was regarded, by some, as a divinely sent "short-cut" to foreign language acquisition that would facilitate the evangelization of the whole world before the Second Coming (5-6). While disappointment on the mission "field" led to the abandonment of this view, it did not dampen the ambitions of missionaries like A.G. Carr and his wife, who left Los Angeles convinced they could speak Bengali (and Chinese and Tibetan), yet stayed in India to preach to Western missionaries and Indian congregations about the new movement's radical eschatological vision.

The second part of the book surveys the beliefs and practices of the South Indian Pentecostal movement, from the varying views regarding gifts of the spirit to the organization of church life. Bergunder spent approximately sixteen months in India, and conducted 191 interviews with pastors, prominent lay people and church leaders, but whether due to his commitment to empiricism, his lack of linguistic skills, or his effort to cover so many topics, movements and regions, Bergunder's analysis of the lived experience of Pentecostalism remains regrettably somewhat thin. This reader longed for more in-depth investigations such as those of anthropologists Joel Robbins and Birgit Meyer, whose studies of Pentecostal and charismatic Christianity in Oceania reveal the complex levels of attraction that the richly embodied, imaginative and even transgressive force of Pentecostalism has for those marginalized, yet aspiring to thrive, in modernizing societies transformed by globalization.

While Bergunder's "pastor's-eye" point of view has some drawbacks, it also leads to the book's most significant strengths. As mentioned previously, the interviews he conducted allowed him access to a wealth of oral tradition 
surrounding the history of the Pentecostal movement in South India. These interviews also lend insight into the challenges and opportunities afforded by the distinctive ecclesiastical structure of the Pentecostal movement. While individual Pentecostal congregations are sometimes bound loosely together into short-lived partnership or interregional denominations, they are mostly autonomous, with a charismatic male leaderfounder at the head of each congregation. Modeling their style of leadership after Old Testament prophets called by God, many of these pastors are unapologetically nondemocratic. According to one pastor, "God always calls one man. That's the Bible. He never called a committee" (209). Consistent with the movement's central spiritual practice of living wholly according to God's will, a great deal of church administration is governed by the "faith principle," whereby pastors strive to depend on God alone to send the resources necessary to achieve His ends. Thus, pastors committed to this principle essentially live on spontaneous gifts from congregants, where the rituals surrounding such gift-giving bear a close resemblance to vow-related rituals found in popular Hinduism and Indian Catholicism (216217). Such erratic sources of revenue, however, do not lend themselves well to careful bookkeeping. Combined with the centralized, even autocratic form of leadership characteristic of
Pentecostal congregations, "the financial administration of the Pentecostal movement is structurally extremely susceptible to almost any kind of abuse" (219).

Bergunder's attention to the administrative nuts and bolts of the Pentecostal movement also sheds light on the somewhat contradictory effects of foreign funding, which has been the object of considerable criticism. On the one hand, Western funders (mostly American, but also Swedish and German) seeking Indian partners exacerbate the instability of interchurch cooperation by providing financial incentives for pastors to start their own churches and compete with each other for members in order to advance (mostly exaggerated) claims to robust church growth. On the other hand, visits from well-known foreign evangelists promote inter-church cooperation when local pastors band together to organize the massive rallies, "Miracle festivals," and Gospel Meetings that are the highlights of the Pentecostal calendar.

Michael Bergunder has done a great service in laying the groundwork for future studies of Pentecostalism in South India. Both the weaknesses and the strengths of the book point to exciting new avenues for further investigation.

Eliza F. Kent

Colgate University

\section{Influences of Ancient Hinduism on Early Christianity. A.L. Herman. Delhi: Motilal Banarsidass, 2009, 246 + xii pages.}

MODERN Hindu apologists have sometimes asserted that Hinduism exerted a rather direct influence on Christianity through its founder, Jesus of Nazareth, as Bradley Malkovsky reminded us in the previous issue of JHCS (23 [2010]: 4-5). Whether through an historical argument about Jesus" "lost years" in India or a theological argument about his status as an avatar and/or self-realized jīvan-mukta, such apologists have been more than happy to claim Jesus as their own, while also, at least in many cases, bemoaning the distortion of his authentic teachings by Paul of Tarsus and subsequent Christian tradition.

Despite the promise of his title, Herman offers something very close to the opposite argument in the present volume. For the "Ancient Hinduism" that represents the source of influence in this study is not the classical Hinduism of the Bhagavad-Gìtā or, much less, Śankara or another great Vedāntin; it is the ancient, sacrificial cult of Siva, as revealed in the Harappan statues and seals of the Indus Valley civilization (c. 2500-1800 BCE). And 